\title{
Demethylchlortetracycline compared with penicillin in the treatment of gonorrhoea in women
}

\author{
WERA ENFORS AND LARS MOLIN \\ From the Department of Dermatology, St. Gorans Sjukhus, Stockholm, and the Department of Dermatology, \\ Karolinska Sjukhuset, Stockholm
}

PENICILLIN, given intramuscularly in a single injection, still remains the treatment of choice in the management of acute gonorrhoea. An antibacterial agent not containing penicillin but giving the same cure rate as penicillin is often desirable when dealing with patients who have a known or possible allergy to penicillin or who absolutely refuse the injection. The ideal drug would be one which would achieve a cure with a single oral dose, have no adverse reactions, and cost little.

During the last decade many studies have been made using various forms of tetracyclines, most of them in male cases. Demethylchlortetracycline (7-chloro-6-demethyltetracycline), DMCT, produced by a mutant strain of Streptomyces aureofaciens and introduced by McCormick, Sjolander, Hirsch, Jensen, and Doerschuk (1957), promised to be a satisfactory agent for single dose therapy because of its slow rate of renal clearance and prolonged serum activity (Kunin and Finland, 1958).

Pochi and Strauss (1961) used a single oral dose of $0.9 \mathrm{~g}$. DMCT to treat 43 males with acute gonorrhoeal urethritis and had a cure rate of 89 per cent. Allison (1961) treated 119 males and four females with $0.6 \mathrm{~g}$. and 108 males and 36 females with $0.9 \mathrm{~g}$. DMCT and reported cure rates of 84 and 93 per cent. respectively. He did not distinguish between males and females when calculating the cure rates.

VanderStoep, Matheson, Moore, Short, and Knox (1964), dealing only with males, compared the results of treatment with $0.6 \mathrm{~g}$. DMCT in 379 cases, $0.9 \mathrm{~g}$. in 426 cases, and $1.2 \mathrm{~g}$. in 492 cases with those obtained using 1.2 mega units procaine penicillin $G$ in oil with 2 per cent. aluminium monostearate (PAM) intramuscularly in 387 cases. They found that 0.9 and 1.2 g. DMCT and 1.2 mega units PAM gave very

Received for publication April 8, 1969.

Present address: Department of Dermatology, Karolinska Sjukhuset, S-104 01 Stockholm 60, Sweden similar cure rates, ranging from 91.5 to 93.2 per cent., while $0.6 \mathrm{~g}$. DMCT gave a cure rate of only 87 per cent.

Willcox (1967) reported on the use of $0.9 \mathrm{~g}$. DMCT given in a single oral dose to 33 males, $1 \cdot 2 \mathrm{~g}$. given to 52 males, and two doses each of $1.2 \mathrm{~g}$. given at an interval of 4 to 6 hours to 34 males. The cure rates were 80,87 , and $85 \cdot 2$ per cent. respectively. When results in Negro patients were excluded, the cure rate with the schedule involving two doses of $1.2 \mathrm{~g}$. DMCT increased to 94.6 to 95.2 per cent.

The aim of the present study was to investigate the results of the treatment of acute uncomplicated gonorrhoea in females using DMCT in a single oral dose and to compare these results with those in a corresponding group of females treated with penicillin.

\section{Material and methods for treatment and follow-up}

Every second woman attending the Outpatient Unit of Venereology and Dermatology at St. Gorans Hospital, Stockholm, Sweden, and suffering from uncomplicated gonorrhoea (verified by results of smears and cultures from the urethra, cervix and rectum) was treated with a single oral dose of $1.2 \mathrm{~g}$. DMCT, and all the other women were treated with 1 mega unit aqueous benzyl penicillin and 1.2 mega units aqueous procaine penicillin in a single injection. There were thus two comparable groups, each comprising 200 females. The dose of penicillin used was that recommended by the Royal Swedish Medical Board as standard treatment for acute gonorrhoea in Sweden at the time when the trial was in progress.

The efficacy of the treatment was checked by four weekly examinations, specimens for smears and cultures being taken from the urethra, cervix, and rectum on each occasion. Seventeen women treated with DMCT and 33 treated with penicillin defaulted; the follow-up groups thus comprised 183 and 167 females respectively.

The ages of all but a few women ranged from 15 to 30 years. 156 had attended spontaneously and 194 had been 
referred as sexual contacts of males with proven gonorrhoeal infection.

\section{Results}

All gonococcal strains isolated were fully sensitive to tetracycline. Table I shows the sensitivities to penicillin of the gonococcal strains isolated from the group treated with penicillin. The method of sensitivity testing is that described by Ericsson (1960).

Table II summarizes the results of the different treatment schedules. In the DMCT-treated group presumably true relapses were demonstrated in 39 cases (22.2 per cent.), 21 of which were evident at the first follow-up examination within one week of treatment. In the penicillin-treated group twelve relapses (7.4 per cent.) were proved.

Gonococci, verified by culture, were found in rectal specimens in the cases of 86 of the 350 women who completed all four follow-up examinations; there were 53 cases in the group treated with DMCT and 33 in the penicillin group. None of the patients had symptoms of proctitis. There were 21 relapses in the DMCT group and three in the penicillin group, giving failure rates of 41.2 per cent. and 9.7 per cent. respectively, taking into account two definite reinfections in each group.

Considering cases of infection limited to the urethra and cervix, the failure rates were 14.5 per cent. in the DMCT-treated group and 6.8 per cent. in those treated with penicillin.

\section{Discussion}

The high incidence of rectal gonorrhoea is notable, and as techniques of culturing gonococci from rectal specimens improve the incidence seems to increase.
In a series of cases from the same city treated in 1968, as many as 49 per cent. of cases of asymptomatic rectal gonorrhoea occurred among 300 females (Molin, 1970). This fact must be taken into account when judging the efficacy of treatment. Unfortunately most of the authors studying the effect of single oral dose treatment have not noted the occurrence of rectal gonorrhoea at the first examination or in cases which relapsed.

This study shows that there is a highly significant difference between the cure rate of those with and those without rectal gonorrhoea treated with DMCT $(\mathrm{P}<0.001)$.

There is also a highly significant difference between the cure rates of those with rectal gonorrhoea treated with DMCT and those treated with penicillin $(\mathrm{P}<0.001)$.

Disregarding rectal gonorrhoea, there still is a significant difference between the cure rate in the DMCT-treated and penicillin-treated groups $(P<0.01)$.

These findings do not agree with those of VanderStoep, Matheson, Moore, Short, and Knox (1964) cited above, who seem to be the only workers to have compared DMCT and penicillin therapy; their cases, however, were in men only.

It was not possible to study any correlation between the results of therapy and the blood levels of DMCT or of penicillin as was done by Allison (1961).

In the DMCT-treated group gastrointestinal reactions such as nausea and vomiting occurred in twenty females, ten of whom were among the 39 who relapsed. This side-effect may have had an influence on the low cure rate.

TABLE I Sensitivity of gonococci to penicillin: first positive culture

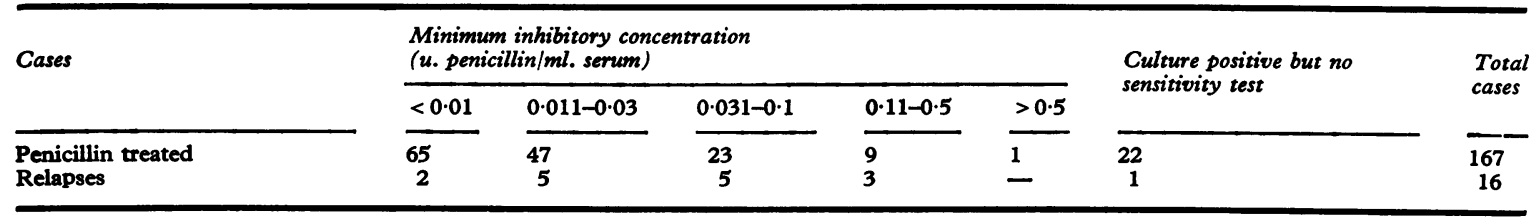

TABLE II Initial treatment and failure to respond

\begin{tabular}{|c|c|c|c|c|c|c|c|}
\hline Diagnosis & Treatment & $\begin{array}{l}\text { Number } \\
\text { followed }\end{array}$ & Re-infections & $\begin{array}{l}\text { Number to be } \\
\text { assessed }\end{array}$ & Relapses & Cures & $\begin{array}{l}\text { Percentage failure } \\
\text { of treatment }\end{array}$ \\
\hline Urethritis and cervicitis & $\begin{array}{l}\text { DMCT } \\
\text { Penicillin }\end{array}$ & $\begin{array}{l}130 \\
134\end{array}$ & $\begin{array}{l}5 \\
2\end{array}$ & $\begin{array}{l}125 \\
132\end{array}$ & $\begin{array}{r}18 \\
9\end{array}$ & $\begin{array}{l}107 \\
123\end{array}$ & $\begin{array}{r}14 \cdot 5 \\
6 \cdot 8\end{array}$ \\
\hline Gonococci in rectal specimens & $\begin{array}{l}\text { DMCT } \\
\text { Penicillin }\end{array}$ & $\begin{array}{l}53 \\
33\end{array}$ & $\begin{array}{l}2 \\
2\end{array}$ & $\begin{array}{l}51 \\
31\end{array}$ & $\begin{array}{r}21 \\
3\end{array}$ & $\begin{array}{l}30 \\
28\end{array}$ & $\begin{array}{c}41 \cdot 2 \\
9 \cdot 7\end{array}$ \\
\hline Total cases & $\begin{array}{l}\text { DMCT } \\
\text { Penicillin }\end{array}$ & $\begin{array}{l}183 \\
167\end{array}$ & $\begin{array}{l}7 \\
4\end{array}$ & $\begin{array}{l}176 \\
163\end{array}$ & $\begin{array}{l}39 \\
12\end{array}$ & $\begin{array}{l}137 \\
151\end{array}$ & $\begin{array}{r}22 \cdot 2 \\
7 \cdot 4\end{array}$ \\
\hline
\end{tabular}


The cases of presumed true relapse may have included some which were really cases of re-infection, the distinction being often controversial. However, it seems reasonable to assume that the incidence of such cases would have been much the same in both treatment groups.

The results of this study do not permit the authors to consider DMCT as a valuable alternative to penicillin in the treatment of gonorrhoea in females, mainly because of its poor effect in those with rectal gonorrhoea.

\section{Summary}

Demethylchlortetracycline in a single oral dose of $1 \cdot 2 \mathrm{~g}$. was compared with $1 \mathrm{mega}$ unit aqueous benzyl penicillin and 1.2 mega units aqueous procaine penicillin in a single injection in the treatment of uncomplicated gonorrhoea in two groups of 200 women each.

The cure rate for penicillin was 92.6 per cent. of 163 cases followed and that for demethylchlortetracycline was 77.8 per cent. of 176 cases followed. Considering those with rectal gonorrhoea, the cure rates were 90.3 and 58.8 per cent. respectively. Contrary to other reports this investigation thus shows that demethylchlortetracycline is not acceptable for single oral dose treatment in female cases of gonorrhoea, since cases involving rectal gonorrhoea responded very poorly.

\section{References}

Allison, J. R., Jr. (1961) Antibiot. and Chemother., 11, 454

ERIcsson, H. (1960) Scand. F. clin. Lab. Invest., 12, Suppl. 50
Kunin, C. M., and Finland, M. (1958) New Engl. $\mathcal{F}$. Med., 259, 999

MCCoRmick, J. R. D., Sjolander, N. O., Hirsch, U., Jensen, E. R., and Doerschuk, A. P. (1957) f. Amer. chem. Soc., 79, 4561

Molin, L. (1970) Acta derm.-venereol. (Stockh.), 50, 157

Pochi, P. E., and Strauss, J. S. (1961) Antibiot. Med., 8, 75

VANDERStoep, E. M., Matheson, T. E., Moore, M. B., ShorT, D. H., and KNox, J. M. (1964) Sth. med. F., 57, 201

Willcox, R. R. (1967) Brit. F. vener. Dis., 43, 157

La déméthylchlortétracycline comparée à la pénicilline dans le traitement de la gonococcie féminine

SOMMAIRE

Une dose unique, buccale, de $1,2 \mathrm{~g}$. de déméthylchlortétracycline a été comparée à 1 méga-unité de benzylpénicilline aqueuse et à 1,2 méga-unités de pénicillineprocaïne en suspension aqueuse données en une seule injection pour le traitement de la gonococcie non compliquée, dans deux groupes chacun de 200 femmes.

Le taux de guérison pour la pénicilline fut de 92,6 pour cent pour les 163 cas suivis et, pour la déméthylchlortétracycline, de 77,8 pour cent pour les 176 cas suivis. Si l'on considère la gonococcie rectale, les taux de guérison ont été, respectivement, de 90,3 et de 58,8 pour cent. Contrairement à d'autres publications, cette recherche montre donc que la déméthylchlortétracycline ne convient pas comme traitement buccal en une seule dose pour la gonococcie féminine. Ceci parce que les cas s'accompagnant de rectite gonococcique ont répondu très mal à cette thérapeutique. 